\title{
Pushover analysis of RC frame structure using ETABS 9.7.1
}

\author{
Santhosh.D ${ }^{1}$ \\ ${ }^{1}$ Assistant professor, Dept. of Civil Engg, \\ Srikrishna institute of technology, Bangalore, Karnataka, India
}

\begin{abstract}
Pushover analysis is a non linear static analysis used to determine the force-displacement relationship, or capacity curve, for a structural element. To evaluate the performance of RC frame structure, a non linear static pushover analysis has been conducted by using ETABS 9.7.1. To achieve this objective, three $R C$ bare frame structures with 5, 10, 15 stories respectively were analyzed. And also compared the base force and displacement of RC bare frame structure with 5, 10, 15 stories.
\end{abstract}

Keywords: ETABS 9.7.1, Hinge properties, Non linear static analysis, Pushover analysis, $R C$ bare frame.

\section{Introduction}

Pushover analysis is non linear static analysis in which provide 'capacity curve' of the structure, it is a plot of total base force vs. roof displacement. The analysis is carried out up to failure, it helps determination of collapse load and ductility capacity of the structure. The pushover analysis is a method to observe the successive damage state of the building. In Pushover analysis structure is subjected to monotonically increasing lateral load until the peak response of the structure is obtained as shown in figure

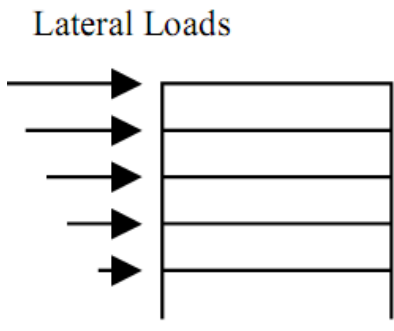

Structural Model

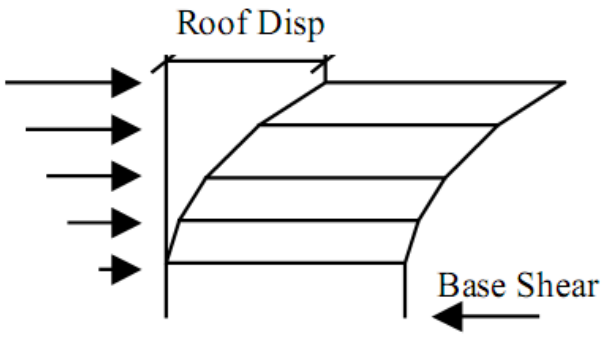

Fig A. Static approximation used in the pushover analysis.

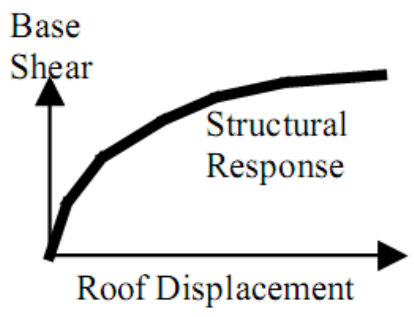

1. FORCE DEFORMATION BEHAVIOR OF HINGES

- Point A corresponds to unloaded condition.

- Point B represents yielding of the element.

- The ordinate at $\mathrm{C}$ corresponds to nominal strength and abscissa at $\mathrm{C}$ corresponds to the deformation at which significant strengthdegradation begins.

- The drop from C to D represents the initialfailure of the element and resistance tolateral loads beyond point $C$ is usuallyunreliable.

- The residual resistance from D to E allows the frame elements to sustain gravity loads.

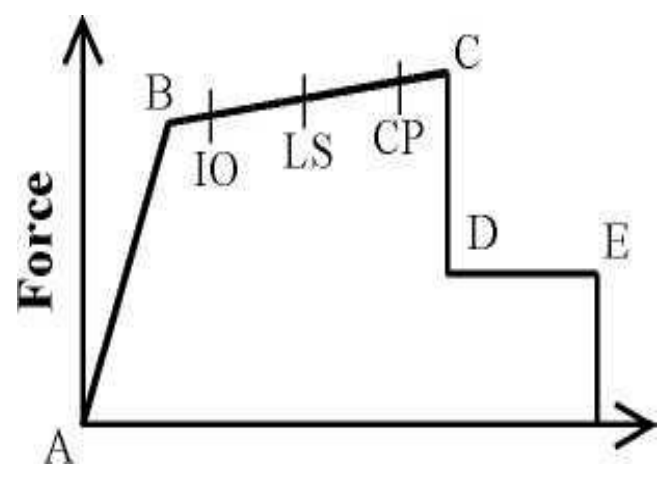

Fig B. Graph shows the curve Force Vs Deformation 
- Beyond point E, the maximum deformationcapacity, gravity load can no longer besustained.

\section{PERFORMANCE LEVELS AND RANGES}

The building performance level is a function of the post event conditions of the structural and non-structural components of the structure. The performance levels are as follows:

- Immediate Occupancy

- Life Safety

- Collapse Prevent

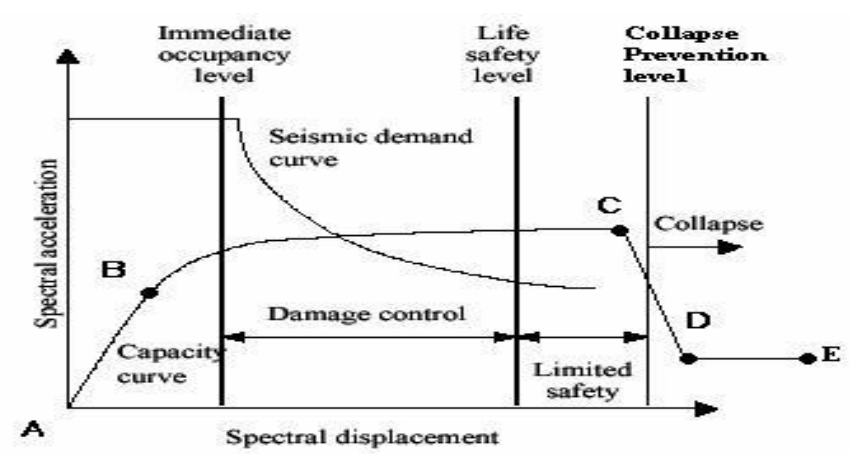

Fig C. Performance levels and ranges

2.1) Immediate Occupancy Performance Level (S-1)

Immediate Occupancy is the post-earthquake damage state in which only very limited structural damage has occurred. In the primary concrete frames, there will be hairline cracking.

2.2) Damage Control Performance Range (S-2)

Structural Performance Range S-2, Damage Control, is the continuous range of damage states that less damage than that defined for the Life Safety level, but more than that defined for the Immediate Occupancy level.

2.3) Life Safety Performance Level (S-3)

Structural Performance Level S-3, Life Safety, is the post-earthquake damage state in which significant damage to the structure has occurred, but some margin against either partial or total structural collapse remains. In the primary concrete frames, there will be extensive damage in the beams. There will be spalling of concrete cover and shear cracking in the ductile columns

2.4) Limited Safety Performance Range (S-4)

Structural Performance Range S-4, Limited Safety is the continuous range of damage states between the Life Safety and Collapse Prevention levels

2.5) Collapse Prevention Performance Level (S-5)

Structural Performance Level S-5, Collapse Prevention, is the building is on the verge of experiencing partial or total collapse. In the primary concrete frames, there will be extensive cracking and formation of hinges in the ductile elements

Performance point - The performance point is the point where capacity curve crosses demand curve.

\section{Material properties}

\section{Data To Be Used}

Modulus of elasticity of concrete, $E_{c}=22360 \mathrm{~N} / \mathrm{mm}^{2}$.

Grade of concrete $=$ M20

Grade of steel $=\mathrm{Fe}-415$

Poissons ratio of concrete $=0.2$

\section{Description of frame structure}

The RC frame structure 5,10, 15 stories is considered in this study.In themodal,in X-direction and Ydirection, each of $5 \mathrm{~m}$ in length and the support condition was assumed to be fixed and soil condition was assumed as medium soil. The seismic zone assumed as zone IV.All slabs were assumed as Membrane element of $120 \mathrm{~mm}$ thickness. The typical floor height is $3 \mathrm{~m}$. The details of beams and columns are shown in table 1.Live load on slab is $3 \mathrm{KN} / \mathrm{m}^{2}$. 
Table 1 Specification

\begin{tabular}{|l|l|}
\hline Beams & Columns \\
\hline $230 \times 450 \mathrm{~mm}$ & $300 X 600 \mathrm{~mm}$ \\
\hline
\end{tabular}

\section{Plan of Structure}

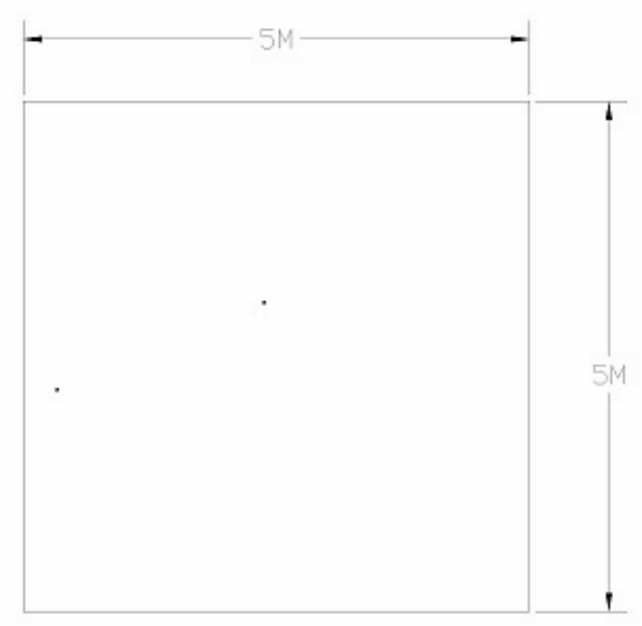

Fig D: plan of structure

\section{III.Static Analysis Of Buildings Using Is 1893 (Part 1)-2002}

1) Design Seismic Base Shear- The total design lateral force or design seismic base shear (Vb) along any principal direction of the building shall be determined by the following expression

$$
\mathrm{VB}=\mathrm{Ah} \mathrm{W}
$$

Where $\quad A h=$ Design horizontal seismic coefficient.

2) Seismic Weight of Building:

$$
\mathrm{W}=\text { Seismic weight of the building }
$$

The seismic weight of each floor is its full dead load plus appropriate amount of imposed load. While computing the seismic weight of each floor, the weight of columns and walls in any storey shall be equally distributed to the floors above and below the storey. The seismic weight of the whole building is the sum of the seismic weights of all the floors. Any weight supported in between the storey shall be distributed to the floors above and below in inverse proportion to its distance from the floors.

3) Fundamental Natural Time Period:

The fundamental natural time period $(\mathrm{Ta})$ calculates from the expression

$\mathrm{Ta}=0.075 \mathrm{~h}^{0.75}$ for RC frame building

For 5 storey, $\quad \mathrm{Ta}=0.075 \times 15^{0.75}=0.57 \mathrm{sec} \quad$ where $\mathrm{h}=15 \mathrm{~m}$

For 10 storey, $\mathrm{Ta}=0.075 \times 30^{0.75}=0.96 \mathrm{sec} \quad$ where $\mathrm{h}=30 \mathrm{~m}$

For 15 storey, $\mathrm{Ta}=0.075 \times 45^{0.75}=1.30 \mathrm{sec} \quad$ where $\mathrm{h}=45 \mathrm{~m}$

4) Distribution of Design Force-

The design base shear, VB computed above shall be distributed along the height of the building as per the following expression

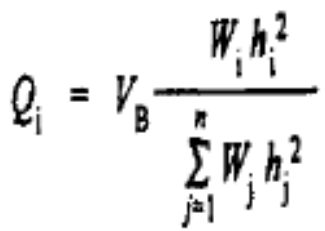

\section{Pushover Analysis}

After assigning all properties of the models, thedisplacement -controlled pushover analysis of the modelsare carried out. The models are pushed in monotonicallyincreasing order until target displacement is 
reached orstructure loses equilibrium. The program includes several built-indefault hinge properties that are based onaverage values from ATC-40 for concretemembers and average values from FEMA-273 for steel members.

- Locate the pushover hinges on model. ETABS provides hinge properties and recommends PMM hinges for columns and M3 hinges for beam as described in FEMA-356.

- Define pushover load cases. IN ETABS more than one pushover load case can be run in the same analysis

\section{Results and Graphs}

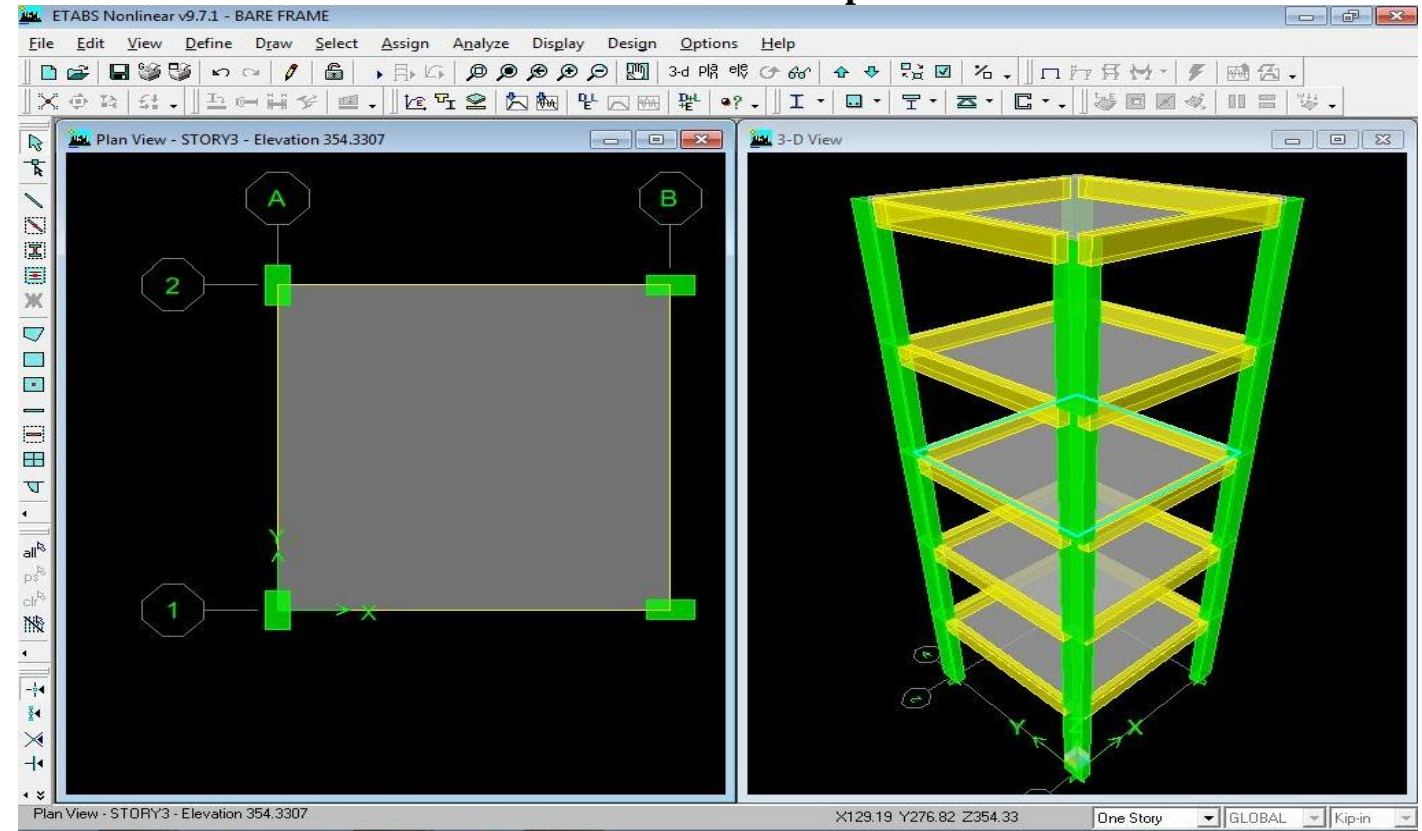

Fig E. Modeling of the structure -5 storey

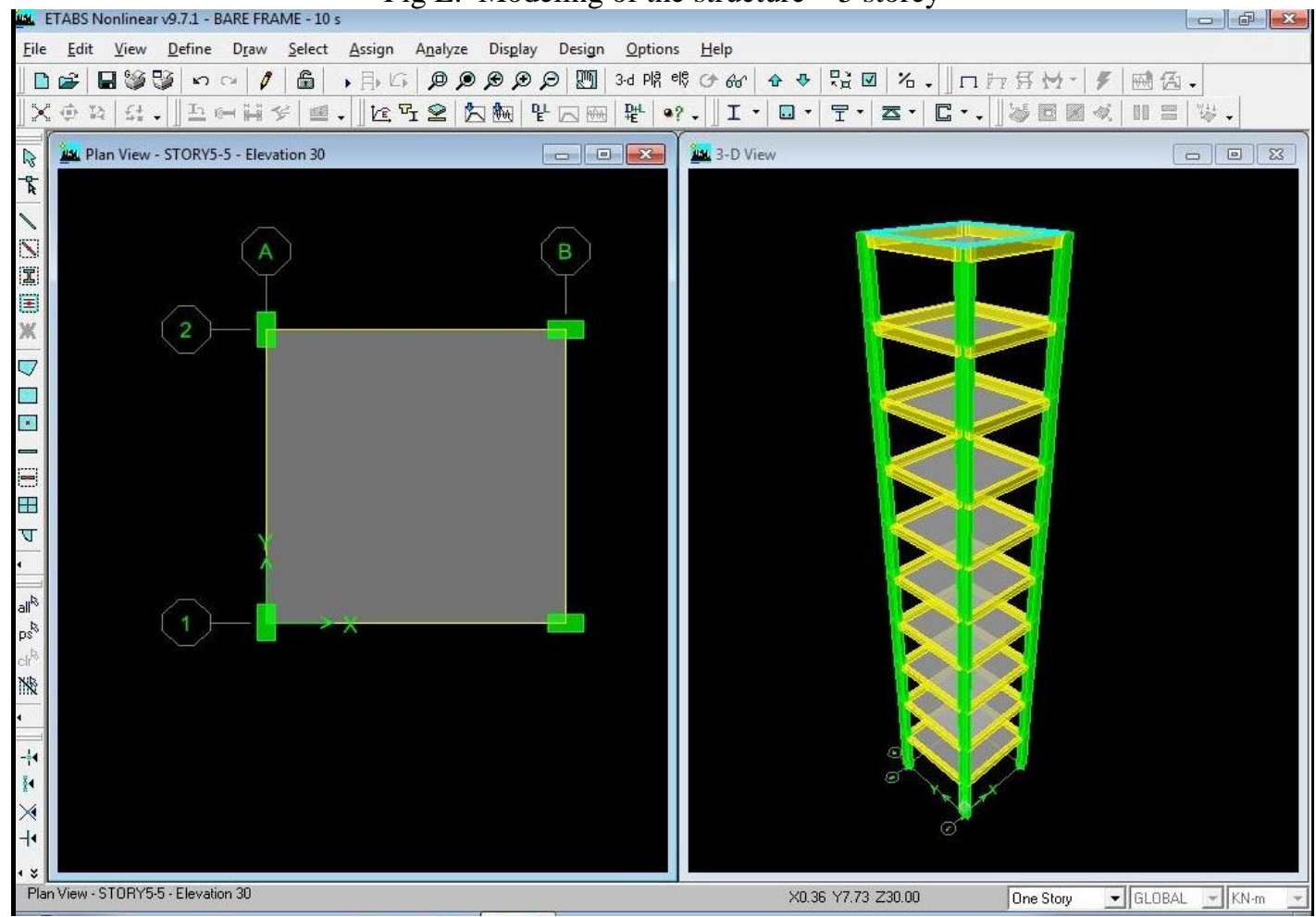

Fig F. Modeling of the structure - 10 storey 


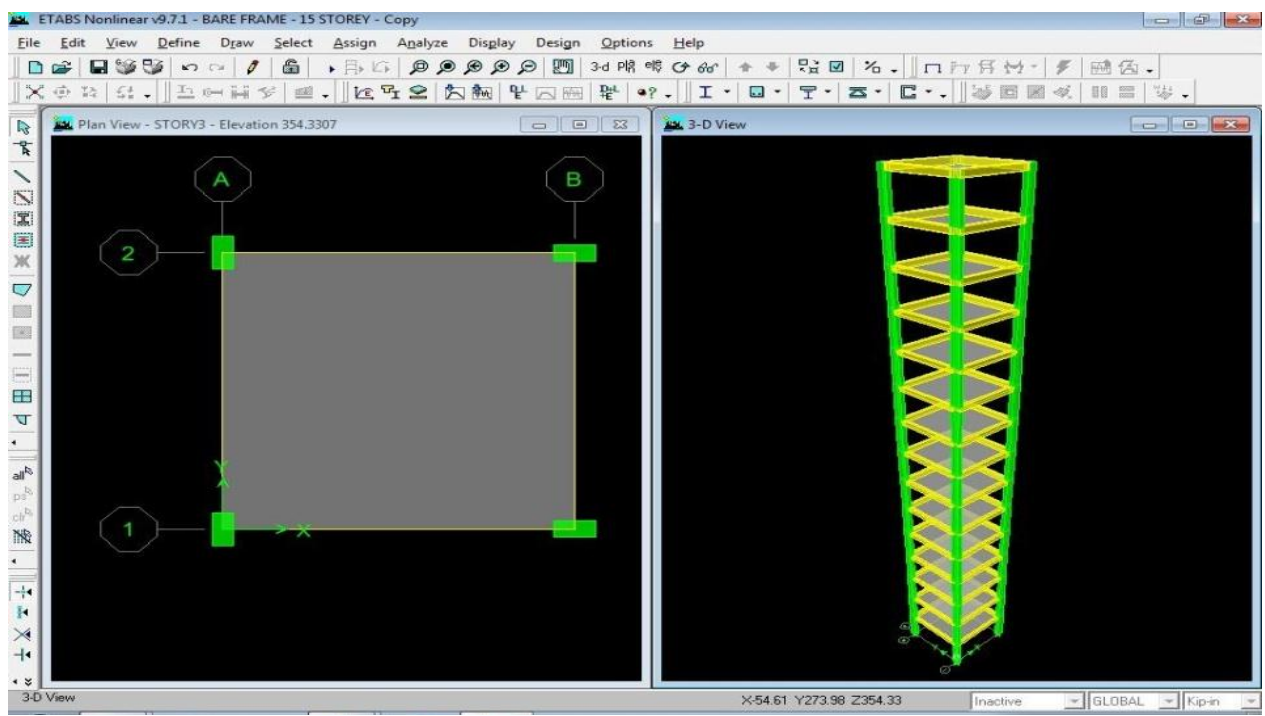

Fig G. Modeling of the structure -15 storey
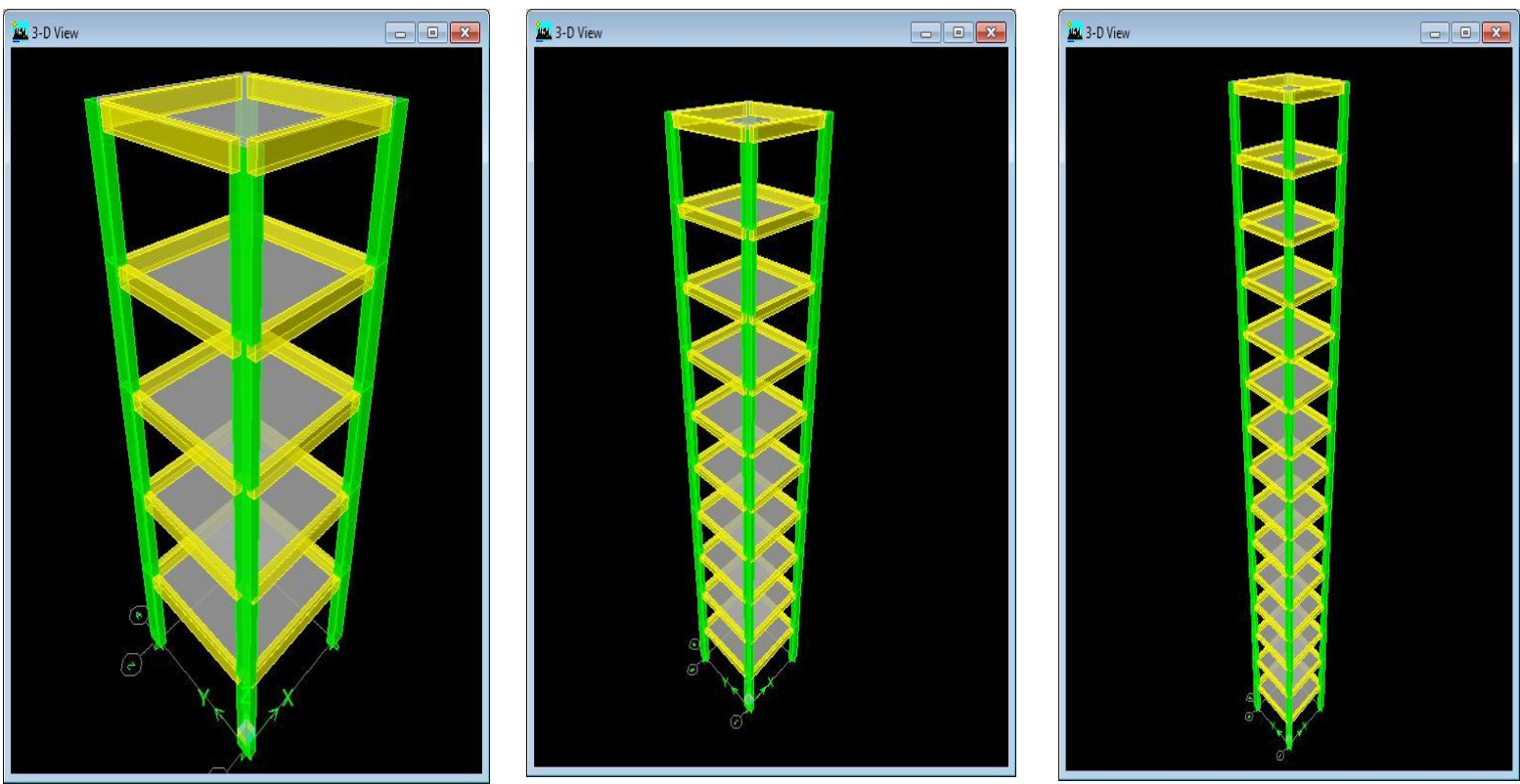

Fig H. Modeling of the structure $-5,10$ and 15 storey
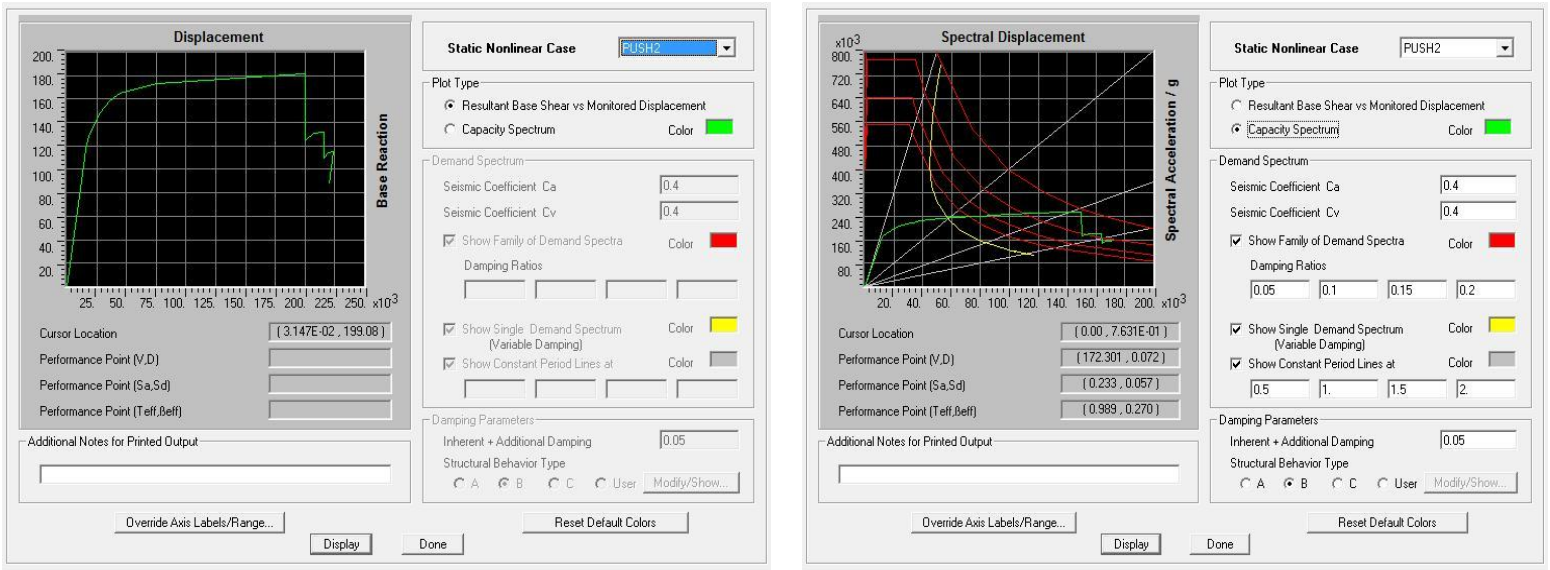

Fig I. Pushover curve and capacity spectrum curve of 5 storey frame structure 
Table 2. Data of pushover curve -5 storey

\begin{tabular}{|c|c|c|c|c|c|c|c|c|c|c|c|}
\hline Steps & $\begin{array}{l}\text { Displacement } \\
(\mathrm{m})\end{array}$ & $\begin{array}{c}\text { Base Force } \\
(\mathrm{KN})\end{array}$ & A-B & B-IO & IO-LS & LS-CP & $\mathrm{CP}-\mathrm{C}$ & C-D & D-E & $>E$ & TOTAL \\
\hline 0 & 0.0000 & 0.0000 & 78 & 2 & 0 & 0 & 0 & 0 & 0 & 0 & 80 \\
\hline 1 & 0.0136 & 103.3671 & 74 & 6 & 0 & 0 & 0 & 0 & 0 & 0 & 80 \\
\hline 2 & 0.0156 & 116.6227 & 72 & 8 & 0 & 0 & 0 & 0 & 0 & 0 & 80 \\
\hline 3 & 0.0187 & 128.0727 & 68 & 12 & 0 & 0 & 0 & 0 & 0 & 0 & 80 \\
\hline 4 & 0.0276 & 148.0758 & 64 & 14 & 2 & 0 & 0 & 0 & 0 & 0 & 80 \\
\hline 5 & 0.0356 & 158.2161 & 60 & 16 & 4 & 0 & 0 & 0 & 0 & 0 & 80 \\
\hline 6 & 0.0446 & 165.1577 & 58 & 18 & 4 & 0 & 0 & 0 & 0 & 0 & 80 \\
\hline 7 & 0.0468 & 166.0575 & 54 & 16 & 10 & 0 & 0 & 0 & 0 & 0 & 80 \\
\hline 8 & 0.0761 & 173.3783 & 54 & 12 & 10 & 4 & 0 & 0 & 0 & 0 & 80 \\
\hline 9 & 0.1031 & 175.1543 & 54 & 4 & 14 & 8 & 0 & 0 & 0 & 0 & 80 \\
\hline 10 & 0.1301 & 176.9303 & 54 & 2 & 14 & 10 & 0 & 0 & 0 & 0 & 80 \\
\hline 11 & 0.1571 & 178.7063 & 54 & 2 & 10 & 14 & 0 & 0 & 0 & 0 & 80 \\
\hline 12 & 0.1841 & 180.4822 & 54 & 2 & 2 & 20 & 0 & 2 & 0 & 0 & 80 \\
\hline 13 & 0.2004 & 181.5562 & 52 & 4 & 2 & 18 & 0 & 0 & 4 & 0 & 80 \\
\hline 14 & 0.2004 & 124.1375 & 50 & 6 & 2 & 18 & 0 & 0 & 4 & 0 & 80 \\
\hline 15 & 0.2069 & 130.9482 & 50 & 4 & 4 & 16 & 0 & 2 & 4 & 0 & 80 \\
\hline 16 & 0.2158 & 132.0359 & 48 & 6 & 4 & 16 & 0 & 0 & 6 & 0 & 80 \\
\hline 17 & 0.2158 & 109.3345 & 48 & 6 & 4 & 16 & 0 & 0 & 6 & 0 & 80 \\
\hline 18 & 0.2191 & 114.3603 & 48 & 4 & 6 & 16 & 0 & 0 & 4 & 2 & 80 \\
\hline 19 & 0.2239 & 114.8572 & 48 & 4 & 6 & 16 & 0 & 0 & 4 & 2 & 80 \\
\hline 20 & 0.2203 & 87.6012 & 80 & 0 & 0 & 0 & 0 & 0 & 0 & 0 & 80 \\
\hline
\end{tabular}
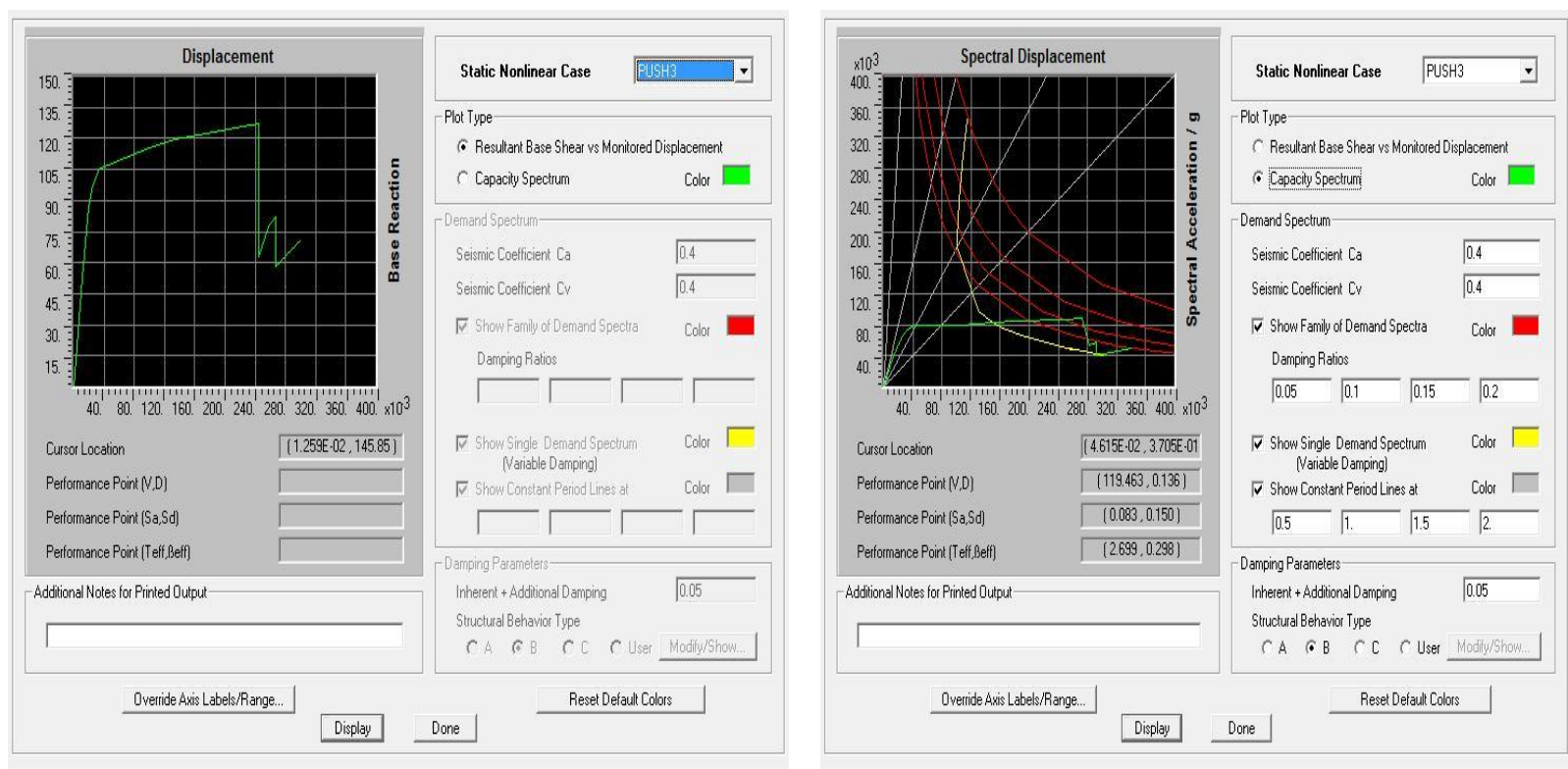

Fig J. Pushover curve and capacity spectrum curve of 10 storey frame structure

Table 3. Data of pushover curve -10 storey

\begin{tabular}{|c|c|c|c|c|c|c|c|c|c|c|c|}
\hline Step & $\begin{array}{c}\text { Displacement } \\
(\mathrm{m})\end{array}$ & $\begin{array}{c}\text { Base Force } \\
(\mathrm{KN})\end{array}$ & A-B & B-IO & IO-LS & LS-CP & CP-C & C-D & D-E & >E & TOTAL \\
\hline 0 & 0.0000 & 0.0000 & 158 & 2 & 0 & 0 & 0 & 0 & 0 & 0 & 160 \\
\hline 1 & 0.0105 & 52.1994 & 148 & 12 & 0 & 0 & 0 & 0 & 0 & 0 & 160 \\
\hline 2 & 0.0199 & 87.1962 & 142 & 18 & 0 & 0 & 0 & 0 & 0 & 0 & 160 \\
\hline 3 & 0.0255 & 97.3409 & 130 & 30 & 0 & 0 & 0 & 0 & 0 & 0 & 160 \\
\hline 4 & 0.0340 & 104.9231 & 128 & 32 & 0 & 0 & 0 & 0 & 0 & 0 & 160 \\
\hline 5 & 0.0364 & 105.9282 & 126 & 12 & 22 & 0 & 0 & 0 & 0 & 0 & 160 \\
\hline 6 & 0.0955 & 114.4206 & 118 & 16 & 26 & 0 & 0 & 0 & 0 & 0 & 160 \\
\hline 7 & 0.1348 & 119.3922 & 118 & 14 & 10 & 18 & 0 & 0 & 0 & 0 & 160 \\
\hline 8 & 0.1648 & 121.7376 & 114 & 16 & 4 & 26 & 0 & 0 & 0 & 0 & 160 \\
\hline 9 & 0.2243 & 126.0053 & 112 & 18 & 4 & 22 & 0 & 4 & 0 & 0 & 160 \\
\hline 10 & 0.2449 & 127.4227 & 112 & 18 & 4 & 22 & 0 & 0 & 4 & 0 & 160 \\
\hline 11 & 0.2449 & 63.0684 & 112 & 18 & 4 & 22 & 0 & 0 & 4 & 0 & 160 \\
\hline 12 & 0.2576 & 77.3997 & 112 & 18 & 4 & 20 & 0 & 2 & 4 & 0 & 160 \\
\hline 13 & 0.2664 & 82.5136 & 110 & 20 & 4 & 20 & 0 & 0 & 6 & 0 & 160 \\
\hline 14 & 0.2664 & 58.3872 & 110 & 20 & 4 & 20 & 0 & 0 & 6 & 0 & 160 \\
\hline 15 & 0.3000 & 71.3378 & 160 & 0 & 0 & 0 & 0 & 0 & 0 & 0 & 160 \\
\hline
\end{tabular}



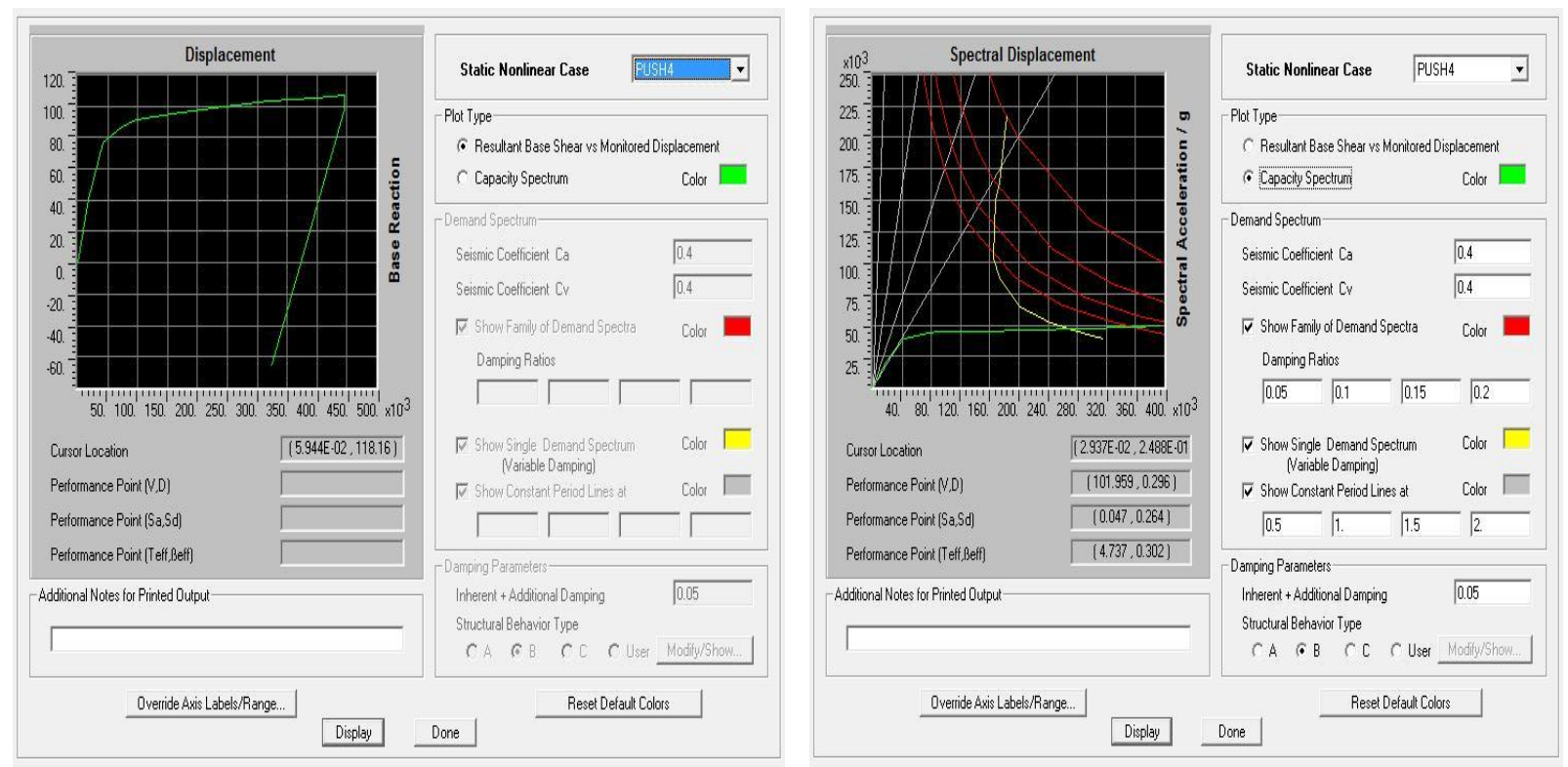

Fig K. Pushover curve and capacity spectrum curve of 15 storey frame structure

Table4. Data of pushover curve -15 storey

\begin{tabular}{|c|c|c|c|c|c|c|c|c|c|c|c|}
\hline Step & $\begin{array}{c}\text { Displacement } \\
(\mathrm{m})\end{array}$ & $\begin{array}{c}\text { Base Force } \\
(\mathrm{KN})\end{array}$ & A-B & B-IO & IO-LS & LS-CP & CP-C & C-D & D-E & T & TOTAL \\
\hline 0 & 0.0000 & 0.0000 & 238 & 2 & 0 & 0 & 0 & 0 & 0 & 0 & 240 \\
\hline 1 & 0.0177 & 40.5246 & 218 & 22 & 0 & 0 & 0 & 0 & 0 & 0 & 240 \\
\hline 2 & 0.0427 & 76.2900 & 212 & 28 & 0 & 0 & 0 & 0 & 0 & 0 & 240 \\
\hline 3 & 0.0470 & 78.8367 & 202 & 38 & 0 & 0 & 0 & 0 & 0 & 0 & 240 \\
\hline 4 & 0.0734 & 87.1870 & 196 & 44 & 0 & 0 & 0 & 0 & 0 & 0 & 240 \\
\hline 5 & 0.0975 & 91.6756 & 194 & 24 & 22 & 0 & 0 & 0 & 0 & 0 & 240 \\
\hline 6 & 0.1565 & 95.1070 & 188 & 18 & 30 & 4 & 0 & 0 & 0 & 0 & 240 \\
\hline 7 & 0.2449 & 99.6026 & 182 & 20 & 8 & 30 & 0 & 0 & 0 & 0 & 240 \\
\hline 8 & 0.3203 & 103.1052 & 178 & 22 & 6 & 34 & 0 & 0 & 0 & 0 & 240 \\
\hline 9 & 0.3978 & 105.6151 & 178 & 20 & 8 & 30 & 0 & 4 & 0 & 0 & 240 \\
\hline 10 & 0.4451 & 107.0373 & 178 & 20 & 8 & 28 & 0 & 2 & 4 & 0 & 240 \\
\hline 11 & 0.4451 & 97.4755 & 172 & 26 & 8 & 28 & 0 & 2 & 4 & 0 & 240 \\
\hline 12 & 0.3238 & -66.4159 & 240 & 0 & 0 & 0 & 0 & 0 & 0 & 0 & 240 \\
\hline
\end{tabular}

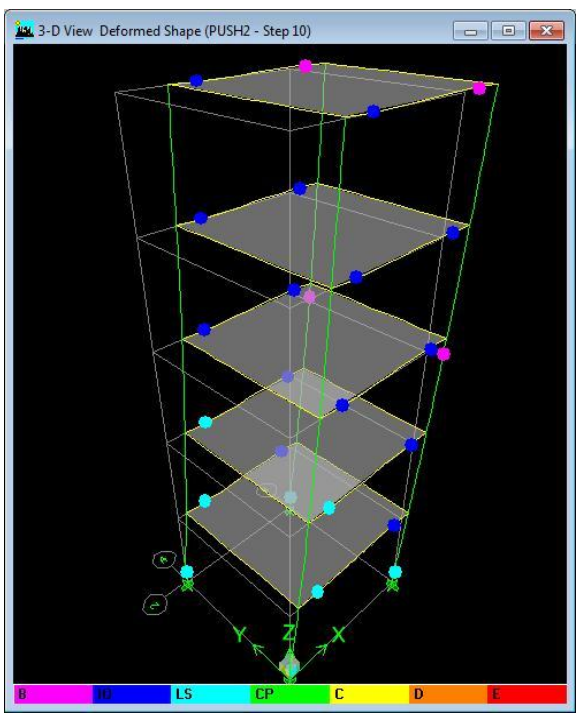

Fig L. Formation of Plastic hinges at step 10 

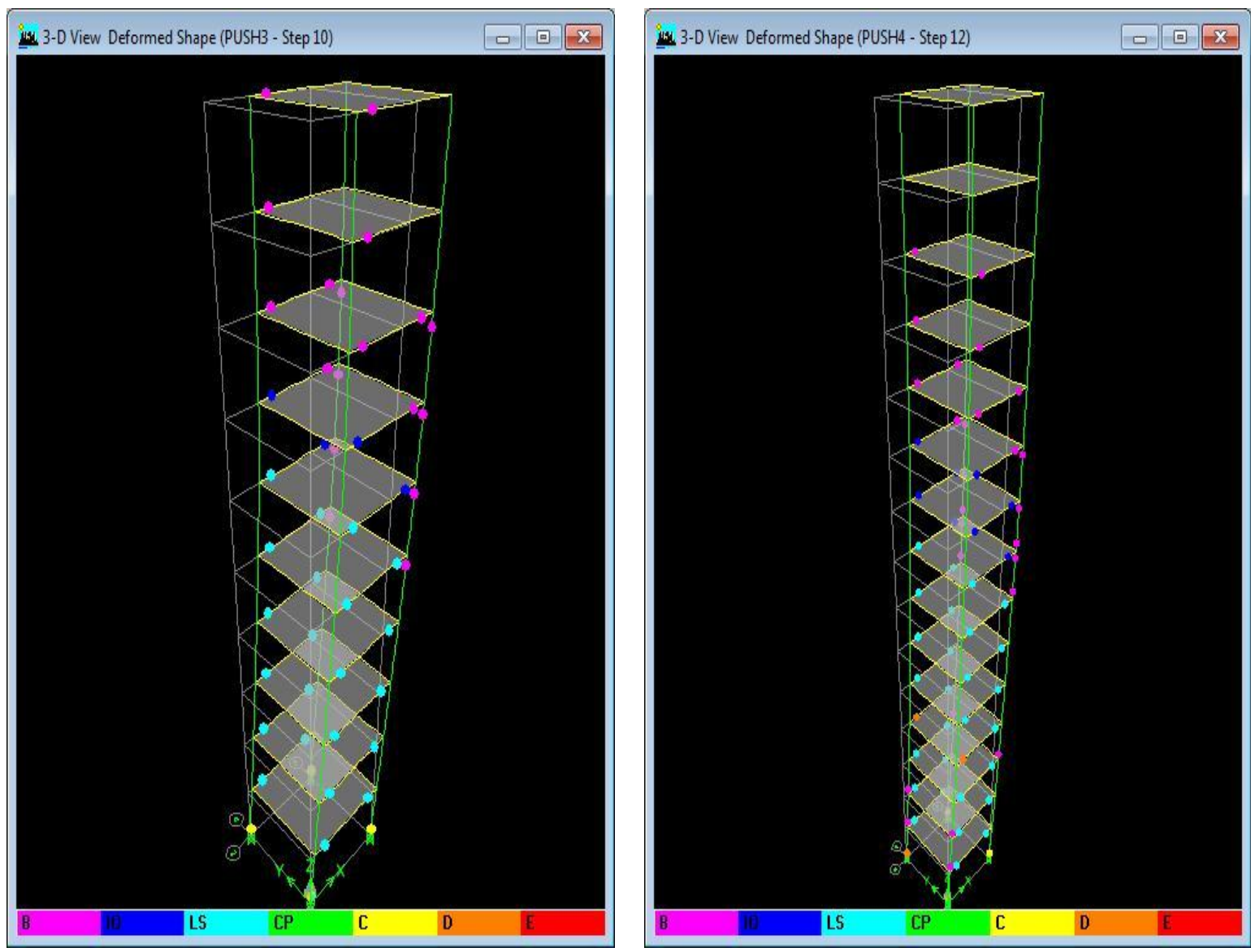

Fig M. Formation of Plastic hinges at step $10 \quad$ Fig N. Formation of Plastic hinges at step 12

\section{V1. Comparison Of Maximum Base Force And Displacement Of 5,10,15Storeys}

Table5. Maximum base force of 5,10,15 storey

\begin{tabular}{|c|c|}
\hline STOREYS & MAXIMUM BASE FORCE ( KN ) \\
\hline 5 Storey & 181 \\
\hline 10 Storey & 127 \\
\hline 15 Storey & 107 \\
\hline
\end{tabular}

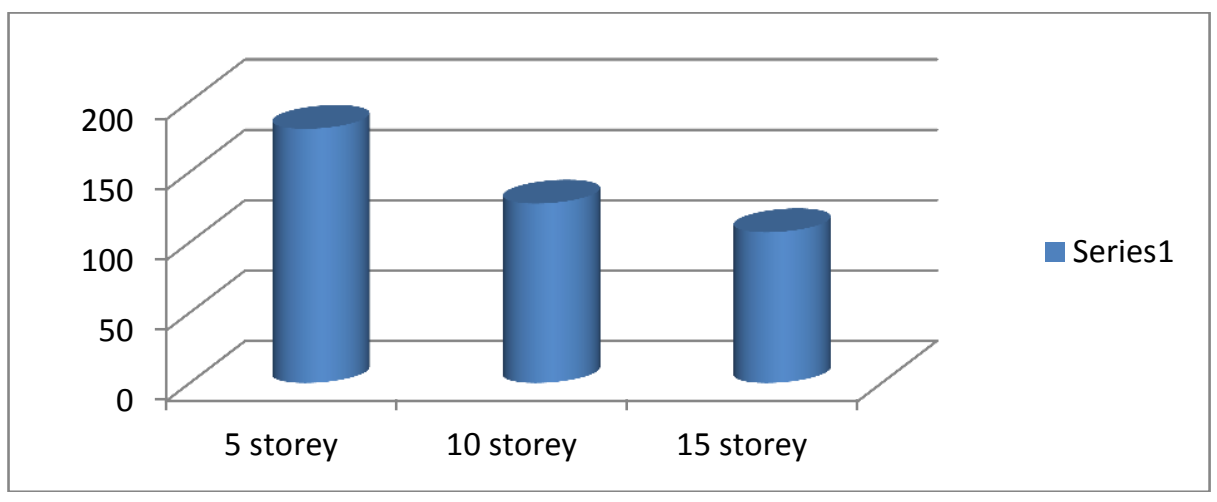

Graph 1. Comparison of maximum base force of 5, 10, 15 storey

Table 6.Maximum displacement of 5, 10, 15 storey

\begin{tabular}{|c|c|}
\hline STOREYS & MAXIMUM DISPLACEMENT $(\mathrm{mm})$ \\
\hline 5 Storey & 22 \\
\hline 10 Storey & 30 \\
\hline 15 Storey & 44 \\
\hline
\end{tabular}




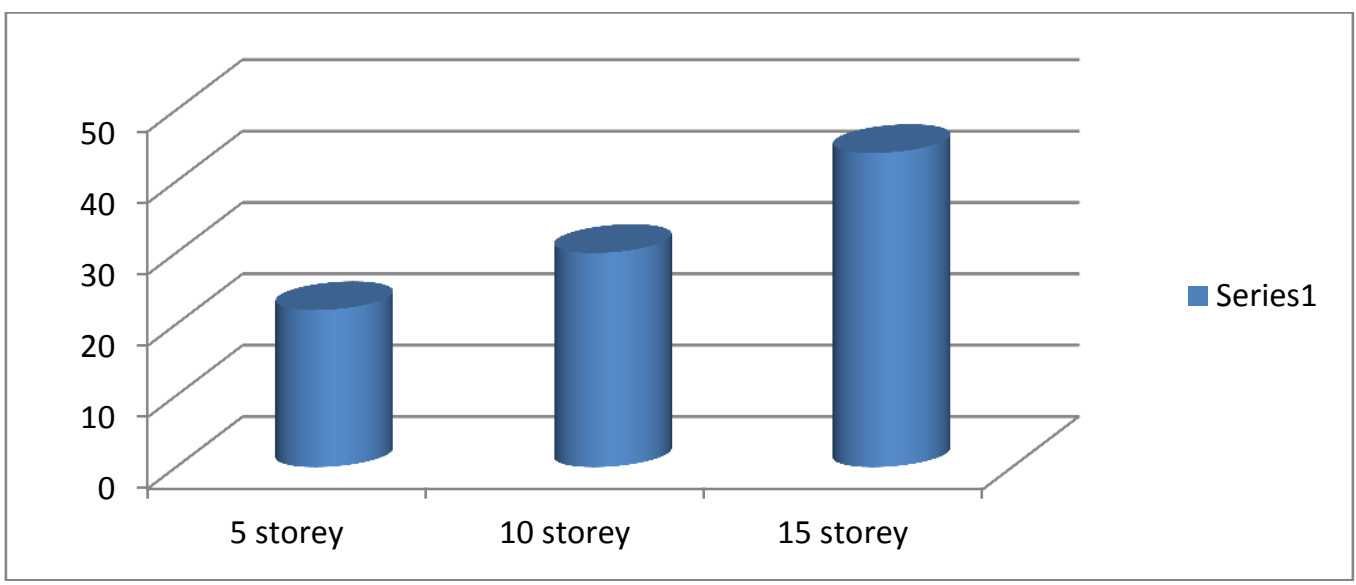

Graph 2. Comparison of maximum displacement of 5, 10, 15 storey

\section{Conclusions}

The performance of reinforced concrete frame was investigated using pushover analysis. These are the conclusions drawn from the analysis:

- The pushover analysis is a simple way to explore the non linear behavior of building.

- In 5 storey frame structure pushover analysis was including 20 steps. It has been observed that, on subsequent push to building, hinges started forming in beams first. Initially hinges were in B-IO stage and subsequently proceeding to IO-LS and LS-CP stage. At performance point, where the capacity and demand meets, out of 80 assigned hinges 54 were in A-B stage, 12,10, and 4 hinges are in BIO, IO-LS and LS-CP stages respectively. As at performance point, hinges were in LS-CP range, overall performance of building is said to be Life safety to Collapse prevention level.

- In 10 storey frame structure pushover analysis was including 15 steps. At performance point, where the capacity and demand meets, out of 160 assigned hinges 118 were in A-B stage, 14,10, and 18 hinges are in BIO, IO-LS and LS-CP stages respectively. As at performance point, hinges were in LS-CP range, overall performance of building is said to be Life safety to Collapse prevention level.

- In 15 storey frame structure pushover analysis was including 12 steps. At performance point, where the capacity and demand meets, out of 240 assigned hinges 182 were in A-B stage, 20,8and 30 hinges are in $\mathrm{BIO}$, IO-LS and LS-CP stages respectively. As at performance point, hinges were in LS-CP range, overall performance of building is said to be Life safety to Collapse prevention level.

- The RC bare frame which is analyzed for the static non linear pushover cases, 5 storey frame can carryhigher base force and at lower displacement it fails

- The RC bare frame which is analyzed for the static non linear pushover cases, 15 storey frame can carry lower base force and at higher displacement it fails.

\section{References}

[1] Srinivasu A and Dr.Panduranga Rao.B, Non-Linear static analysis of multi-storied building, International journal of engineering trends and technology(ILETT) - volume 4 issue 10-oct 2013.

[2] Mrugesh D. Shah, Nonlinear static analysis of RCC frames(software implementation ETABS 9.7), National conference on recent trends in engineering \& technology-May 2011

[3] Chopra AK.Dynamics of structure: theory and application to earthquake engineering.(ERnglewood cliffs,NJ:1995)

[4] IS 1893(part 1):2002, Criteria for earthquake resistant design of structures, Part 1 General provisions and buildings, Bureau of Indian standard,2002. 